\title{
Design and Development of Mobile Phone using Quality Function Deployment
}

\author{
Hamid Ullah and Asiyah Ali

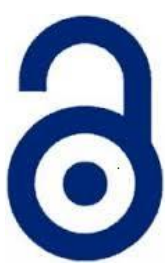 \\ Received: 22 November 2016 \\ Accepted: 17 February 2017 \\ Published: 31 March 2017 \\ Publisher: Deer Hill Publications \\ (c) 2017 The Author(s) \\ Creative Commons: CC BY 4.0
}

\begin{abstract}
This paper presents design and development of mobile phone where quality function deployment approach is used to convert customer needs into design specifications. Customer needs and their relative importance are identified through the analysis of customer survey. Technical requirements that could fulfill the customer needs are established and a relationship matrix is developed between the customer needs and the technical requirements. The relationship matrix is then converted into the house of quality matrix. Using output from the house of quality, concepts of a mobile phone are generated. Concept generation is followed by concept selection where finally an improved model of a new mobile phone is presented.
\end{abstract}

Keywords: Customer needs, Technical requirements, House of Quality (HOQ), Quality Function Deployment (QFD), Concept generation, Concept selection.

\section{INTRODUCTION}

Yoji Akao is considered as the father of QFD who introduced the concept of QFD in Japan in 1966. The Japanese phrase "hinshitsu kino tenkai" matches to "Quality Function Deployment", where "function" corresponds to the analysis of the business process to enhance the quality of products in the development process (Akao and Mazur, 2003). The first use of QFD was made in 1972 by Professor Mizuno to Mitsubishi's Kobe shipyard site in the design of super tankers (Martins and Aspinwall 2001).

Company's success lies in knowing the customer needs and foreseeing the modifications required in the already available products (Soota et al. 2008). Innovation-based companies may push a technology into the market by those who design the product to those who produce it and to those who distribute it in the market (D.R. Kiran, 2017). Therefore, it is very essential for any firm to develop the quality of its product (or service) by bridging the gap between product quality and customer satisfaction (Lin 2007). QFD is the best tool to convert the customer preferences into quality attributes. It is a powerful development tool for achieving product development, improving product quality, reducing time to market, and decreasing the cost of production. It is a famous design tool that considers systematically the customer needs and preferences in product planning and therefore has good applications in manufacturing and service organizations (Dijkstra and Bij, 2002). QFD is a method for developing a quality design by incorporating the consumer demands into design specifications (Akao 1990). Basically, it is aimed to fulfill customer preferences of the product (Kasim et al., 2009). It is a customer driven technique (Guinta and Praizler, 1993). It is broadly spreading in business organizations because of its wonderful usefulness.

QFD is a planning tool that guides the design, manufacturing, and marketing of products (Chan and Wu, 2003). It uses planning matrices that connect customer requirements, design and target specifications, and competitive performance into one graph. It is a helpful tool that facilitates planning, decision-making, and communication in the product development phase. At its heart is the 'Voice of Customer', which gives it the unified stage throughout the product planning and development process. It takes the 'Voice of Customer' throughout the product development process out into the market place. The resulting new product will delight the customers and outshine the competition provided the QFD is done thoroughly (Pun et al., 2000).

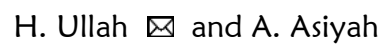

Mechanical Engineering Programme

Faculty of Engineering, Universiti Teknologi Brunei

Jalan Tungku Link, Brunei Darussalam

E-mail: hamid.ullah@utb.edu.bn

Reference: Ullah, H. and Asiyah, A. (2017). Design and Development of Mobile Phone using Quality Function Deployment. International Journal of Engineering Materials and Manufacture, 2(1), 1-10. 
QFD reduces the gap between organization and its customers. To achieve the objective, it is necessary to know the customer needs so that, these could be considered from the early stages of the planning process. It involves implementing technological solutions, by experts, to determine the customer requirements. QFD provides significant advantages, for example: to reduce design and development time, to spotlight the satisfaction of customers, and to increase communication at all levels of an organization (Kasim et al., 2009). It speeds up changes during the various phases of product development. It can assist product designers to identify important design attributes and also provide suggestions for possible improvements in these attributes (Liu, H-T and Cheng, H-S., 2016). Because of these advantages, it has become an accepted support to the product planning and development process (Akao and Mazur, 2003; Chan and Wu, 2002; Chan and Wu, 2003; Day, 1993). It is a historically proven means of guiding process development by using technical performance measures for a systematic organization of all independent variables and their interrelationships. It is cited as a key facilitating method in simultaneous engineering (Menon et al., 1994), and is the most extensive implementation of Total Quality Management (Sage, 1992).

The crucial step in QFD is to derive the prioritization of design specifications from customer needs for a product (Yan and Ma 2015). The successful implementation of QFD lies in the accurate capturing and prioritization of the customer requirements (Kamvysi et al. 2014). While the new customer needs have a major effect on the product successfully, the traditional requirements may not be forgotten by the product's designers (Ashtiany, M.S, and Alipour, A., 2016). The identification and prioritization of customer needs could also be achieved through integration of Kano's model, Analytical Hierarchy Process (AHP) technique and QFD matrix (Hosna Pakizehkar et al., 2016). QFD therefore has been broadly spreading in the industrial and business organizations because of its wide and diverse usefulness. The key planning part of QFD is the House of Quality (HOQ). The customer needs are called 'WHATS' while the technical specifications are called 'HOWS' in the HOQ matrix. The paper is organized as follows: section 2 describes methodology. Section 3 mentions mission statement of the product. It is followed by identifying customer needs and establishing their relative importance in section 4. Defining Technical requirements is presented in section 5. Building House of Quality for mobile phone is discussed in section 6 . Section 7 describes ranking of technical requirements which is followed by concept generation and concept selection presented in sections 8 and 9 respectively. At the end, discussion and conclusion are presented.

\section{METHODOLOGY}

Survey questionnaire is designed to get feedback from the end users' of mobile phone in Brunei Darussalam with respect to their preferences from a new mobile phone. The survey questionnaire consists of twenty (20) questions: eleven (11) multiple choice questions, one (1) ranking question and 8 open ended questions. The questionnaire is distributed online to the customers. The web link of the questionnaire is shared through email, social media such as Facebook and WhatsApp messages. Out of 100 mobile phone end users, response is received from 85 respondents. Data collected is interpreted in terms of customer needs. Relative importance is assigned to the customer needs on a scale of 1 to 5 (where 1 indicates the least important need and 5 indicates the most important need). The customer needs, their relative importance, and technical requirements are used in building HOQ for the mobile phone. The input from the HOQ is used in concept generation phase of mobile phone. Concept generation is followed by concept selection of mobile phone. CAD model of the improved mobile phone is presented.

\section{MISSION STATEMENT}

A mission statement provides a basic functional description of the product, identifies its target market, and also specifies its business goals. The mission statement for the mobile phone is provided in Table 1.

\section{IDENTIFYING CUSTOMER NEEDS AND ESTABLISHING THEIR RELATIVE IMPORTANCE}

Aim of this phase is to identify the customer needs and requirements and to effectively communicate to the product design and development team. The idea behind the technique is to create high-quality information guide that runs directly between the developers of the product and the customers in the target market. This idea is made on the principle that those responsible for the direct control of the details of the product must interact with customers and also experience the use environment of the product. From the survey questionnaire distributed among the end users, the data collected is compiled into the Voice of Customer (VOC). The VOC is converted into customer needs. There are different terminologies used for customer needs. These include customer wants, customer preferences, customer choices, customer wishes, customer expectations, and customer requirements. The customer needs are called 'WHATS' in the HOQ matrix and acts as a first building block in building the HOQ and is the most important phase of QFD. Once the customer needs have been identified, their relative importance is determined. The value of relative importance of the customer need is necessary to obtain the value of the weighted average for the relationship matrix in the HOQ. The customer needs and their relative importance are shown in Table 2. The average value of relative importance shown in Table 2 is assigned on the basis of customer feedback. The features are rated on a scale of 1 to 5 . 
Table 1: Mission statement for the mobile phone.

\begin{tabular}{|c|c|}
\hline Product Description & Mobile phone with basic and advanced features \\
\hline Key main objectives & $\begin{array}{l}>\quad \text { Product introduced in 1th Q of } 2017 \\
\quad 50 \% \text { gross margin } \\
>\quad 10 \% \text { share of mobile phone market by } 2020\end{array}$ \\
\hline Primary market & $\begin{array}{ll}> & \text { Executives } \\
> & \text { Youngsters } \\
> & \text { Students } \\
\end{array}$ \\
\hline Secondary market & $\begin{array}{ll} & \text { Middle Class } \\
> & \text { Casual users } \\
\end{array}$ \\
\hline Assumptions & $\begin{array}{ll}> & \text { Water proof } \\
> & \text { Solar chargeable } \\
> & \text { Touch screen } \\
> & \text { Dual Sim } \\
> & \text { Light weight }\end{array}$ \\
\hline Stakeholders & $\begin{array}{ll}> & \text { Users } \\
> & \text { Design department } \\
> & \text { Manufacturing / production department } \\
> & \text { Sale force and service center } \\
> & \text { Legal department }\end{array}$ \\
\hline
\end{tabular}

\section{DEFININC TECHNICAL REQUIREMENTS}

The next step in the QFD technique is to identify a list of suitable technical requirements that could meet the customer needs. These requirements translate the customer needs into quantifiable terms. These requirements define how to respond to the customer needs. The technical requirements need to be measureable so that it could be determined that the customer needs are satisfied. At least one technical requirement is identified for each customer need. Other terminologies used for technical requirements are: engineering characteristics, quality attributes, design requirements, and voice of company. The technical requirements are called 'HOWS' in the HOQ matrix. Technical requirements that could meet the customer needs are provided in Table 2.

Table 2: Customer needs (their relative importance) and technical requirements.

\begin{tabular}{|c|c|c|c|}
\hline No. & Customer needs & $\begin{array}{l}\text { Relative importance of } \\
\text { customer needs }\end{array}$ & Technical requirements \\
\hline 1 & High camera resolution & 4.88 & $\begin{array}{ll}> & \text { High MP camera resolution } \\
> & \text { LED flash } \\
> & \text { Autofocus }\end{array}$ \\
\hline 2 & External memory card slot & 4.77 & $\begin{array}{l}>\text { Micro SD (secure digital) card slot } \\
>\quad \text { Pin ejection button }\end{array}$ \\
\hline 3 & High internal memory & 5.12 & $\begin{array}{l}>\quad \text { Built in storage } \\
>\quad \text { High RAM }\end{array}$ \\
\hline 4 & Battery is removable & 4.5 & $\begin{array}{ll}> & \text { Non built in battery } \\
> & \text { High battery capacity } \\
> & \text { Fast charging battery }\end{array}$ \\
\hline 5 & Wireless charger & 4.38 & $\begin{array}{ll}> & \text { Fast Wireless charging pad } \\
> & \text { Travel adapter } \\
> & \text { Micro USB adapter }\end{array}$ \\
\hline 6 & Long lasting battery life & 5.31 & $\begin{array}{ll}> & \text { Non built in battery } \\
> & \text { High battery capacity } \\
> & \text { Fast charging battery }\end{array}$ \\
\hline 7 & Fast operating system & 5.23 & $\begin{array}{ll}> & \text { Latest OS } \\
>\quad \text { High RAM }\end{array}$ \\
\hline 8 & Durable screen & 4.36 & $\begin{array}{l}\quad \text { Corning Gorilla Glass } 4 \\
\quad \text { IP } 68 \text { material (dust and water } \\
\text { resistant) } \\
>\quad \text { Tempered glass screen protector }\end{array}$ \\
\hline
\end{tabular}




\begin{tabular}{|c|l|c|l|}
\hline 9 & Large screen & 4.12 & $>$ Screen to body ratio \\
\hline 10 & Waterproof & 4.96 & $\begin{array}{l}>\text { IP } 68 \text { material } \\
>\text { Plastic coated speaker } \\
>\text { Rubber protection USB port }\end{array}$ \\
\hline 11 & Dual SIM card slot & 3.48 & $\begin{array}{l}> \\
>\text { Single nano SIM card slot } \\
>\end{array}$ \\
\hline 12 & Sual SIM card (MMC slot)
\end{tabular}

\section{BUILDING HOUSE OF QUALITY FOR MOBILE PHONE}

Using the above data (customer needs, their relative importance and technical requirements) a $\mathrm{HOQ}$ is built. $\mathrm{HOQ}$ is an important element of QFD. It gives a central part to how well the technical requirements address the customer needs. The HOQ is shown in Figure 1. The customer needs (WHATS) are shown in the $2^{\text {nd }}$ leftmost column of the HOQ matrix while the technical requirements (HOWS) are shown in the topmost row in HOQ. The customer needs are followed by their relative importance presented in the $3^{\text {rd }}$ leftmost column of the matrix. The cells after the column for the relative importance show the interrelationship between the customer needs and the technical requirements. There may be 'no relationship', 'weak relationship', 'medium relationship', or 'strong relationship' between the customer needs and the technical requirements. The weights assigned to these relationships are $0,1,5$, and 10 respectively. The values of 1,5 and 10 are shown in the HOQ matrix by the symbols shown in Table 3 . A blank cell in the matrix shows 'no relationship' between the customer needs and the technical requirements. Purpose of the interrelationship is to translate the customer needs into the technical requirements. This interrelationship matrix is a two-dimensional matrix containing cells that relate to the combinations of individual customer need and technical requirement.

After all calculations have been made, the top five rankings appears to be IP68 casing, micro SD card slot, nonbuilt-in battery, high battery capacity, and plastic coated speaker respectively. The roof of the HOQ shows the correlation among the technical requirements. The plus $(+)$ sign in a cell of the roof shows that improving a particular technical requirement causes improvement in the technical requirements of the corresponding cells. A minus (-) sign could be used in a cell if improving a technical requirement causes deterioration in the technical requirements of the corresponding cells. The symbols used for the interrelationship between the customer needs and the technical requirements are shown in Table 3. The correlation among the technical requirements obtained from the roof of $\mathrm{HOQ}$ is shown in Table 4.

\section{RANKINC OF TECHNICAL REQUIREMENTS}

It is the final element of the HOQ. It is achieved from the weighted average of the technical requirements in the interrelationship matrix of the $\mathrm{HOQ}$. It provides a summary of the conclusions drawn from the information contained in the entire matrix of the HOQ. It presents a priority score and ranks all the technical requirements in the $\mathrm{HOQ}$ matrix. The ranking of the technical requirements is shown in the HOQ matrix.

Table 3: Legend of symbols for House of Quality.

\begin{tabular}{|c|l|c|}
\hline$(0$ & Strong Relationship & 10 \\
\hline$\bigcirc$ & Medium Relationship & 5 \\
\hline$\Delta$ & Weak Relationship & 1 \\
\hline
\end{tabular}




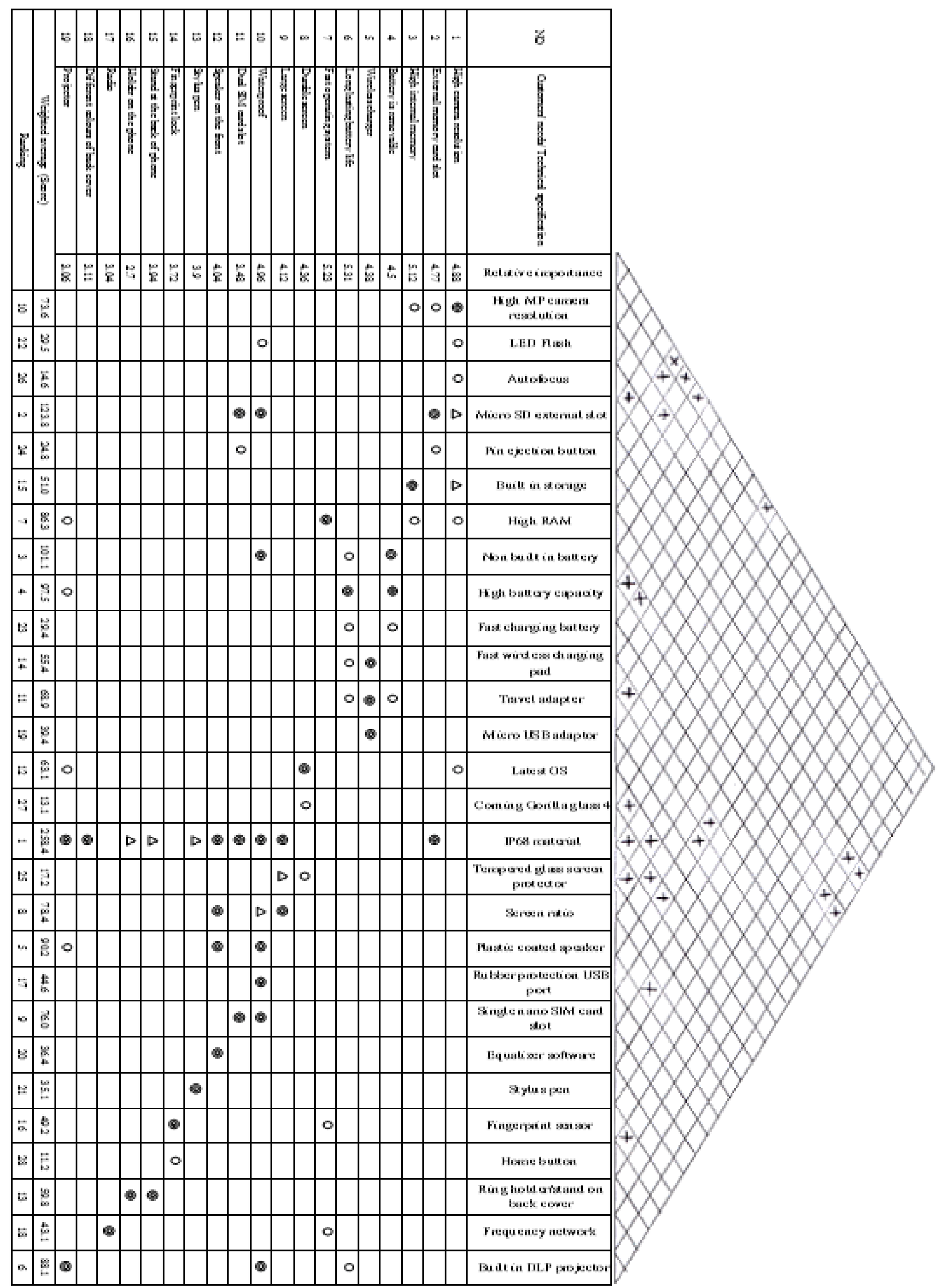

Figure 1: House of Quality 
Table 4: Correlation among technical requirements.

\begin{tabular}{|l|c|l|l|}
\hline High camera resolution & $\uparrow$ & $>$ Built in storage & $\uparrow$ \\
\hline LED flash & $\uparrow$ & $>$ Bigh RAM & $\uparrow$ \\
\hline Micro SD external slot & $\uparrow$ & $>$ Pin ejection & $\uparrow$ \\
\hline High RAM & $\uparrow$ & $>$ Frequency network & $\uparrow$ \\
\hline High battery capacity & $\uparrow$ & $>$ Fast charging battery & $\uparrow$ \\
\hline Travel adaptor & $\uparrow$ & $>$ Fast wireless charging pad & $\uparrow$ \\
\hline Corning gorilla glass 4 & $\uparrow$ & $>$ IP 68 & $\uparrow$ \\
\hline IP 68 & $\uparrow$ & $>$ Screen ratio & Plastic coated speaker \\
\hline Plastic coated speaker & $\uparrow$ & $>$ Eubber protection USB port & $\uparrow$ \\
\hline Fingerprint lock & $\uparrow$ & $>$ Home button & $\uparrow$ \\
\hline
\end{tabular}

\section{CONCEPT GENERATION}

Mobile phone concepts are generated using the input from the HOQ. Three concepts of the improved mobile phone are generated. All the three concepts are designed in rectangular shape. Based on the input from end users of mobile phone, features such as front and back camera, speaker, switch button, ring holder are included in the concepts. Concept 1 shown in Figure 2 has the features of home button, screen and front camera. On the right side, there are volume and switch button. On the back side of the mobile phone, the back camera is circular in shape and there is a dual flash and ring holder attached to the back cover. The battery is removable and there is external memory card and SIM card slots covered by the back cover of mobile phone. The speaker is designed on the bottom side of the mobile phone together with the USB charging port. On the top side of the mobile phone, there is a hole for earphone plug.

In concept 2, shown in Figure 3, the back side of the mobile phone is almost the same as that of concept 1. The camera shape is rectangular. The switch button is on the right of the top side. The speaker is at the front of the mobile phone. There are dual flash for both front and back cameras. The home button is rectangular in shape while, it is circular in case of concept 1. The external memory card and SIM card slots are at the left side of the mobile phone. Concept 3 is shown in Figure 4. There are few similarities between concept 2 and concept 3 . The difference between concept 3 and concept 2 is that the front camera is larger in size and the ring holder is circular in shape.

\section{CONCEPT SELECTION}

Final concept is selected based on the criteria shown in Table 5. The evaluation matrix provides concept 2 to be the final best concept. The selected concept is modeled using Autodesk Inventor Professional 2015. The design specifications of the final concept are presented in Table 6. The final concept could be considered for subsequent development activities. 


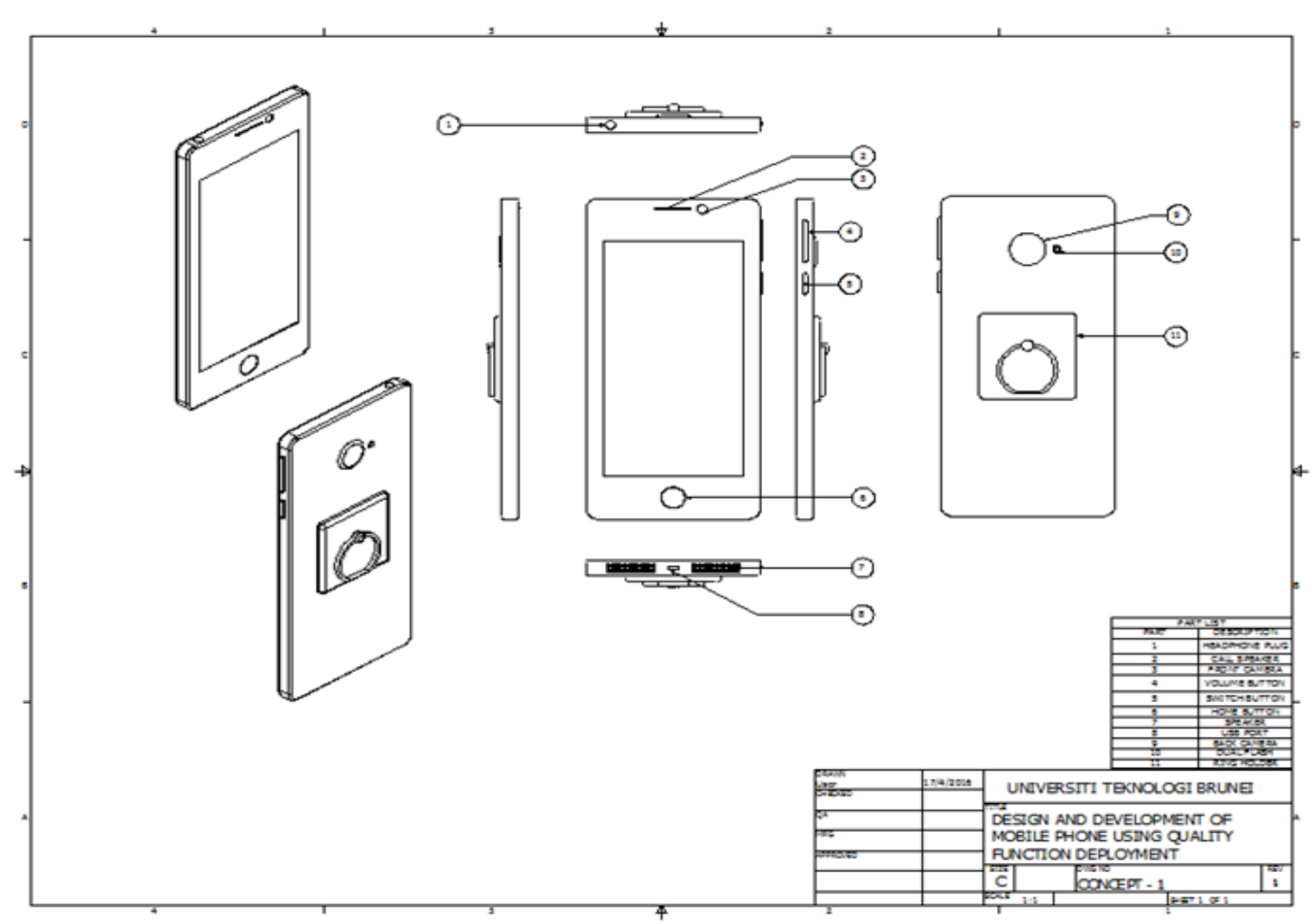

Figure 2: Concept 1

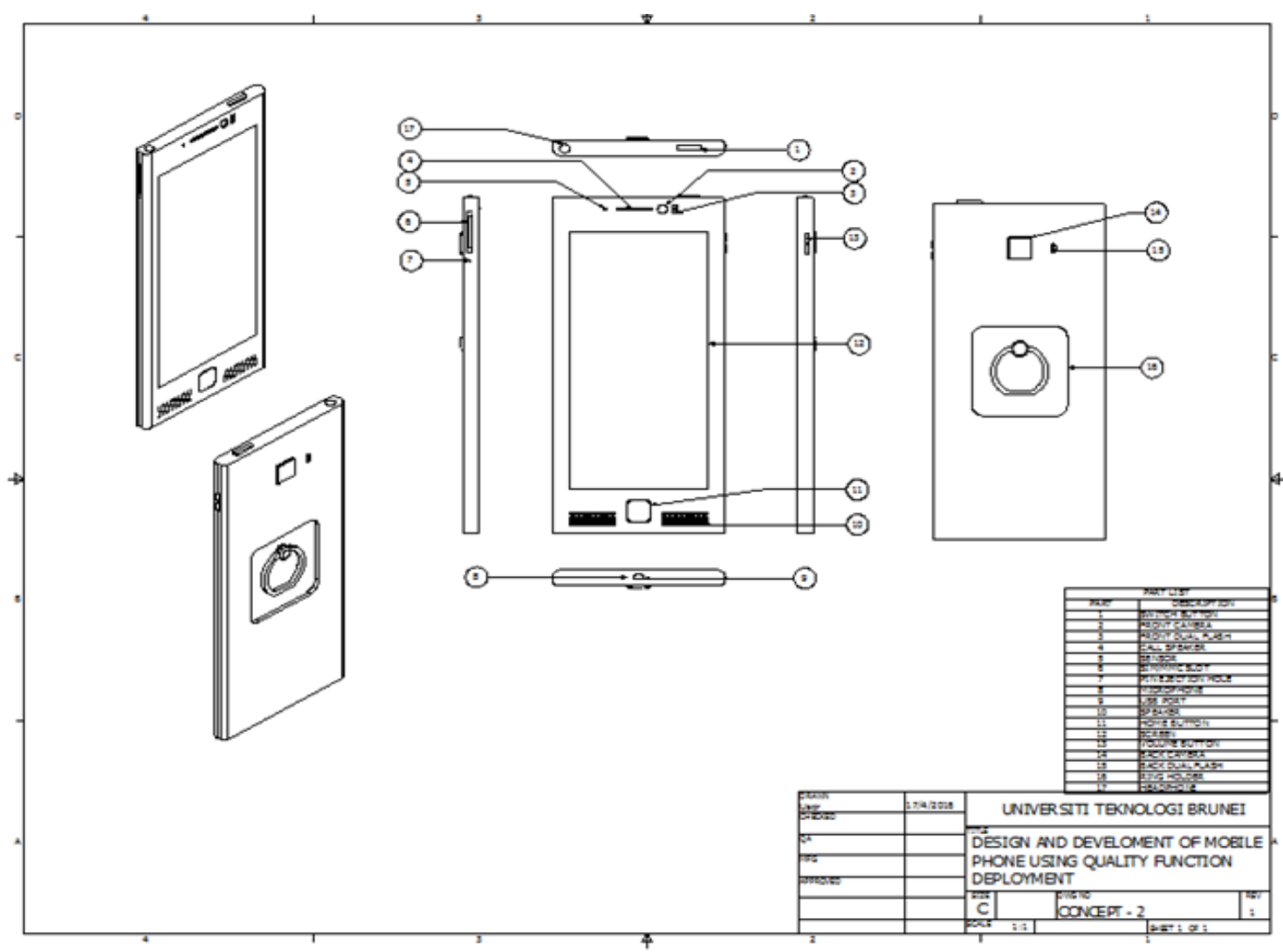

Figure 3: Concept 2 


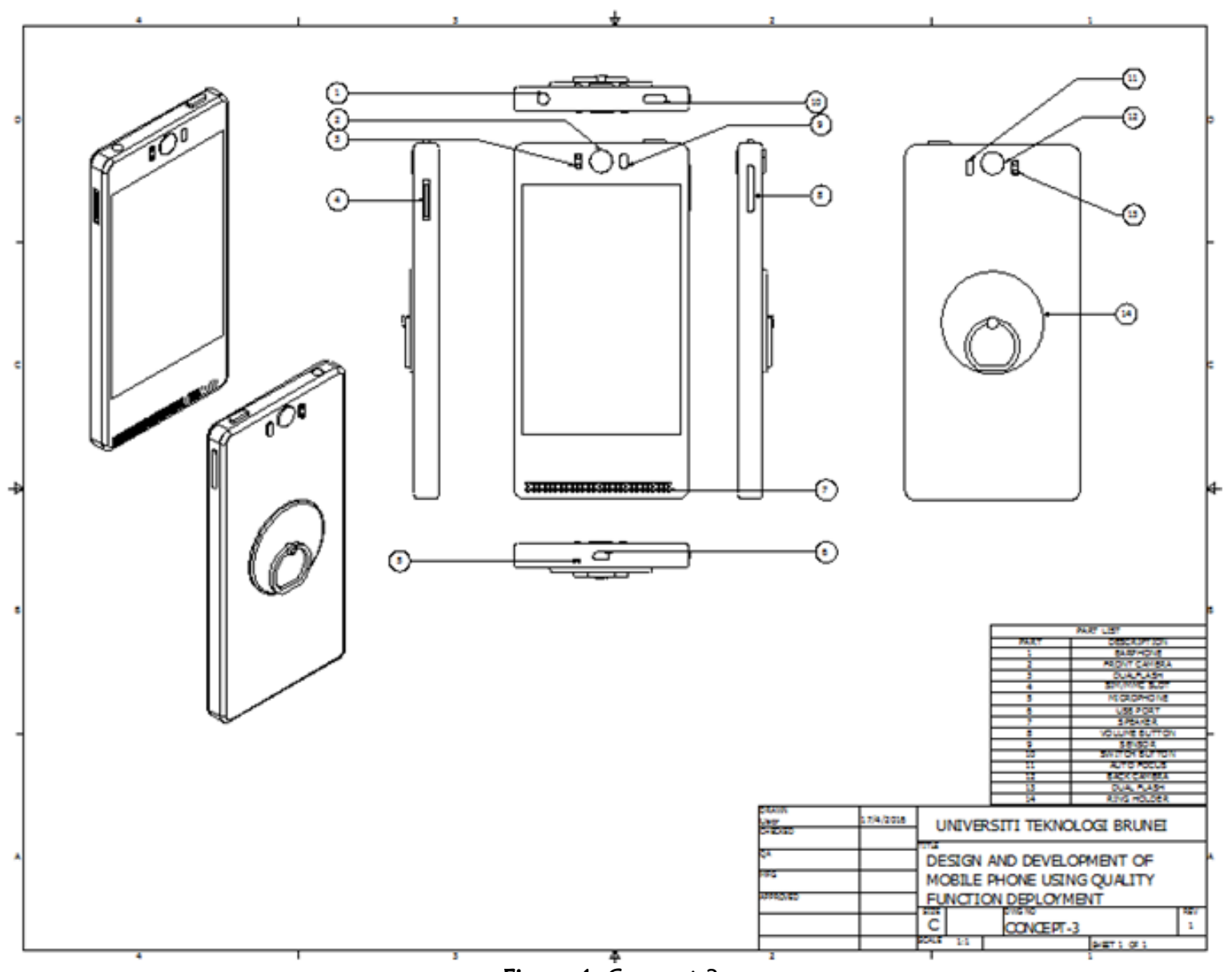

Figure 4: Concept 3

Table 5: Evaluation matrix for concept selection.

\begin{tabular}{|l|c|c|c|}
\hline \multicolumn{1}{|c|}{ Criteria } & \multicolumn{2}{c|}{ Concepts } \\
\hline & 1 (Datum) & 2 & 3 \\
\hline Aesthetic & & + & - \\
\hline Cost & & - & + \\
\hline Weight & & - & 0 \\
\hline User friendliness & & + & - \\
\hline Durability & & - & 0 \\
\hline Easy to manufacture & & 0 & 1 \\
\hline Safety & & 3 & 2 \\
\hline Sum "+" & & 3 & 4 \\
\hline Sum "-" & & 1 & -1 \\
\hline Sum "0" & & 0 & 2 \\
\hline Net score & & 1 & \\
\hline Ranking & & & \\
\hline
\end{tabular}


Table 6: Design specifications of the concept selected.

\begin{tabular}{|l|l|}
\hline Dimensions & $142 \mathrm{~mm} \times 70 \mathrm{~mm} \times 08 \mathrm{~mm}$ \\
\hline Body build & $\begin{array}{l}\text { Corning gorilla glass 4: the toughest glass material for mobile phone, } \\
\text { IP } 68 \text { material }\end{array}$ \\
\hline Screen size & $58 \mathrm{~mm} \times 115 \mathrm{~mm}$ \\
\hline Operating system & Android OS, Marshmallow: latest updated operating system \\
\hline CPU & Quad-core $2.3 \mathrm{GHZ}$ \\
\hline Memory card slot & Micro SD up to $200 \mathrm{~GB}$ \\
\hline Internal storage & $128 \mathrm{~GB}$ with $4 \mathrm{~GB}$ RAM \\
\hline Camera & $\begin{array}{l}\text { Front camera: 08 MP with dual LED flash } \\
\text { Back camera: } 13 \mathrm{MP} \text { with autofocus and dual LED flash }\end{array}$ \\
\hline Battery & Removable battery with a capacity of 3000 mAh \\
\hline
\end{tabular}

\section{DISCUSSION AND CONCLUSIONS}

Mobile phone is designed and developed using QFD technique. Customer requirements (Voice of Customer) of a new mobile phone are identified by conducting a market survey. VOC is converted into customer needs. Customer needs and their relative importance are identified. HOQ for the mobile phone is built. Final specifications of the mobile phone are established. In the design specifications, the dimensions of the mobile phone are $142 \mathrm{~mm} \times 70$ $\mathrm{mm} \times 08 \mathrm{~mm}$. The screen size is $115 \mathrm{~mm} \times 58 \mathrm{~mm}$ which is about $70 \%$ of the front side of the mobile phone. The mobile phone is operated with the latest operating system which in Android Marshmallow version 6.0. Quad core $2.3 \mathrm{GHz}$ is chosen for the fastest processor of the mobile phone.

To be long lasting or durable, Corning Gorilla Glass 4 is specified for body of the mobile phone. IP 68 material is specified for the mobile phone to make it waterproof. External memory card slot is provided for more efficient storage. Micro Secure Digital (MSD) card is specified to fit up to $200 \mathrm{~GB}$, the maximum capacity for external storage. The slot is incorporated with SIM card slot. The mobile phone can hold two SIM cards at the same time where the memory card slot is used for second SIM card. High camera resolution is included. In order to get good resolution, both front and back cameras have their own dual LED flash. They have high mega pixel for better resolution. A removable battery in the mobile phone is located at its back covered by the back cover. It has high capacity of $3000 \mathrm{mAh}$ so that the mobile phone can function longer. There is a ring holder attached to the back cover of the mobile phone. It acts as a convenient and safe grip to prevent falling of the mobile phone while in use. It can also be used as a stand while watching videos by the mobile phone.

In conclusion, QFD is very important method for development of new products according to customer needs. It helps to improve the existing product by taking into account customer requirements and is therefore a very good planning tool. It is worth to mention that the survey questionnaire is distributed within various universities in Brunei Darussalam. Majority of the respondents are students. In future research, diverse users of mobile phone could be considered for taking their input to develop mobile phone. Also, instead of relying only on survey questionnaire, other modes of data collection, for example, one-on-one interview, focus groups, and observing the product in use could be considered.

\section{REFERENCES}

1. Akao, Y. (1990). Quality Function Deployment: Integrating Customer Requirements into Product Design. Productivity Press, Cambridge.

2. Akao, Y., Mazur, G. H. (2003). The leading edge in QFD: Past, present and future. International Journal of Quality \&Reliability Management, 20(1), 20-35.

3. Ashtiany, M. S, and Alipour, A. (2016). Integration Axiomatic Design with Quality Function Deployment and Sustainable design for the satisfaction of an airplane tail stakeholders. Procedia CIRP 53 (2016), the 10th International Conference on Axiomatic Design, ICAD 2016, 142 - 150.

4. Chan, L., Wu, M. (2002). Quality function deployment: A literature review. European Journal of Operational Research, 143(3), 463-497.

5. Chan, L. K. and Wu, M. L. (2003). Quality Function Deployment: A Comprehensive Review of Its Concepts and Methods. Quality Engineering, 15(1), 23-35.

6. Day, R. G. (1993). Quality function deployment: Linking a company with its customers. ASQC Quality Press, Milwaukee. 
7. Dijkstra, L. and Bij, H. (2002). Quality function deployment in healthcare: Methods for meeting customer requirements in redesign and renewal. International Journal of Quality \& Reliability Management, 19(1), 6789.

8. Guinta, L. R. and Praizler, N. C. (1993). The QFD Book: The Team Approach to Solving Problems and Satisfying Customers through Quality Function Deployment. Amacom, New York.

9. Hosna, P., Sadrabadi, M. M., Rasool, Z. M. \& Amir, E. E. (2016). The application of integration of Kano's model, AHP technique and QFD matrix in prioritizing the bank's substructions, 3rd International Conference on New Challenges in Management and Organization: Organization and Leadership, 2 May 2016, Dubai, UAE, Procedia - Social and Behavioral Sciences 230, pp. 159 - 166, doi: 10.1016/j.sbspro.2016.09.020.

10. Kamvysi, K., Gotzamani, K., Andronikidis, A. \& Georgiouc, A.C. (2014). Capturing and prioritizing students' requirements for course design by embedding Fuzzy-AHP and linear programming in QFD. European Journal of Operational Research, 237(3),1083-1094.

11. Kasim, M. daws, Zuhair, A. A, Amer A. M. (2009). An Intelligent Quality Function Deployment (IQFD) for Manufacturing Process Environment. Jordan Journal of Mechanical and Industrial Engineering, 3(1), $23-30$.

12. Kiran, D.R. (2017). Quality Function Deployment, Total Quality Management: Key Concepts and Case Studies, Chapter 30, Elsevier B.V., 425-437.

13. Lin, W.B. (2007). An empirical of service quality model from the viewpoint of management. Expert Systems with Applications, 32, 364-75.

14. Liu, H-T and Cheng, H-S. (2016). An improved grey quality function deployment approach using the grey TRIZ technique. Computers \& Industrial Engineering, 92, 57-71.

15. Martins, A. and Aspinwall, E.M. (2001). Quality function deployment: an empirical study in the UK. Total Quality Management, 12(5), 575-588.

16. Menon, U. et al. (1994). Quality function deployment: An overview. In C. Syan and U. Menon (Eds.), Concurrent engineering - concepts, implementation and practice, London: Chapman and Hall, 90-99.

17. Pun, K.F., Chin, K.S., and Lau, H. (2000). A QFD/hoshin approach for service quality deployment: a case study. Managing Service Quality, 10(3), 156-169.

18. Sage, A. (1992). Systems engineering. Fairfax, VA: George Mason University, School of Information Technology and Engineering, 278-284.

19. Soota, T., Singh, H., and Mishra, R. (2000). Defining Characteristics for Product Development Using Quality Function Deployment: A Case Study on Indian Bikes. Quality Engineering, 20(2), 195 - 208.

20. Yan, H-B and Ma, T. (2015). A group decision-making approach to uncertain quality function deployment based on fuzzy preference relation and fuzzy majority. European Journal of Operational Research, 241(3), 815829. 